\title{
Effects of physical and chemical properties on the dissolution of
} sea salt

\author{
Nguyen Huu Lan, Nguyen Thi Ngoc Huong, Pham Huu Thinh, Lai Quoc Dat, Nguyen Hoang Dzung*
}

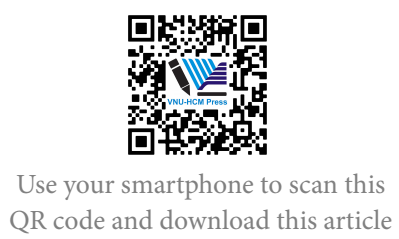

Department of Food Technology, Ho Chi Minh City University of Technology, VNU-HCM, Ho Chi Minh City, Vietnam

\section{Correspondence}

Nguyen Hoang Dzung, Department of Food Technology, Ho Chi Minh City University of Technology, VNU-HCM, Ho Chi Minh City, Vietnam

Email: dzung@hcmut.edu.vn

History

- Received: 25-3-2021

- Accepted: 27-5-2021

- Published: 03-6-2021

DOI : 10.32508/stdjet.v4i2.822

\section{Check for updates}

\section{Copyright}

(.) VNU-HCM Press. This is an openaccess article distributed under the terms of the Creative Commons Attribution 4.0 International license.

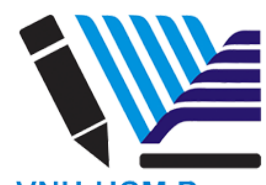

VNU-HCM Press

\begin{abstract}
Salt plays a crucial role in human health. However, excess use of $\mathrm{NaCl}$ in food products can be harmful to health. One suggestion for this problem is optimization salt dissolution to increase the content of salt ions in the mouth. For this purpose, it is important to understand the solubility properties of salt crystals in saliva. The dissolving process is not only affected by the physical properties but also by the chemical composition of the salt. This study compared the solubility of four commercial grain salts in four regions in Vietnam (Bac Lieu, Thanh Hoa, Sa Huynh, Vung Tau), one flower salt in Sa Huynh and a control sample with two particle sizes $1-2 \mathrm{~mm}$ and $2-3 \mathrm{~mm}$ in a Saliva Artificial Gal - Fovet solution (SAGF). Dissolution was determined by analyzing microscopic images taken by the time and analysis by Bayesian and Partial Least Squared methods. The research evaluated the influence of physical properties (area, Feret's diameter, circularity, aspect ratio and solidity) and chemical compositions (sodium, potassium, magnesium, calcium and moisture content) on the dissolving process. Salt samples showed significant differences in physical and chemical properties by region. Morphological parameters are affected by conditions of salt crystallization that indicated through region of origin. Dissolution is evaluated through solubility coefficient, Sa Huynh flower salt and control salt have the highest solubility coefficient, simultaneously, it is also the smallest value of roundness and surface index. The projected area, magnesium and sodium content are the factors which strongly affecting on dissolution of salt samples. These results demonstrated the possibility to exploit these factors to adjust the solubility of salt as well as the perceived salinity over time.
\end{abstract}

Key words: salt, artificial saliva, dissolution, physico-chemical properties, Bayesian

\section{INTRODUCTION}

Sodium is an essential nutrient for maintaining blood plasma, acid-base balance, transmit nerve impulses and participate in necessary functions for human cells $^{1,2}$. Sodium is found naturally in many foods, such as milk, meat, and seafood. Besides, in some processed foods, snacks, spices (sodium glutamate) are also sources of sodium for the body ${ }^{3}$. Nowadays, most people are consuming too much salt, averaging 9 to $12 \mathrm{~g}$ per day, which is approximately twice the maximum recommended intake (World Health Organization, 2014). High sodium in the diet can lead to high blood pressure, cardiovascular disease, and stroke ${ }^{4,5}$. It can also cause calcium losses, some of which may be pulled from bone ${ }^{6}$. Therefore, it is necessary to develop strategies that reduce the level of sodium intake while maintaining the salt taste perception in products.

There are many different suggestions for increasing salt salinity, such as using salt alternatives or altering the chemical composition by adding a salt additive, thereby reducing sodium intake body ${ }^{7}$. Previous studies showed that from 70 to $95 \%$ sodium (or NaCl salt) can remain in food matrix after a consumer has swallowed it ${ }^{8,9}$. For dry foods that are salted directly to the surface, a significant amount of sodium can be swallowed completely without the consumer perceiving the salty taste. The difference in salty taste is actually caused by the dissolution of the salt in the mouth by saliva. In it, saliva acts as a solvent to distribute ions in salt to the taste receptors on the tongue ${ }^{10}$. Therefore, the dissolving process of salt will directly affect the taste of salt in consumers.

Several methods have been developed to study salt dissolution in the mouth e.g. installing ionic electrodes in the mouth. However, this technique has limitations as the levels recorded may not fully reflect the signal received by the taste buds. Furthermore, having a string in the mouth can make chewing difficult ${ }^{11}$. For this reason, in vitro methods have been developed with easier implementation while still providing data for screening ${ }^{12}$. These methods developed systems that simulate conditions in the mouth and the use of natural or artificial saliva in experiments in which salt solubility is measured using a conductivity probe or observation system. By this method, Vella, D. et al 
(2012) found a significant difference between the size of salt particles and its close correlation with the dissolution rate ${ }^{12}$. Beside that, Quilaqueo, M. et al (2015) analyzed the dissolution rate of the salt by video $\mathrm{mi}$ croscopy images taken at different times. The results revealed that the solubility rate of salt crystals in water is higher than in artificial saliva and at higher temperatures. The increased surface area after fragmentation results in pyramid-shaped crystals having the highest dissolution rates ${ }^{8}$. Hence, significant changes in salt dissolution can be achieved depending on its crystal structure and soluble form.

In order to optimize the salty taste felt in the mouth, it is essential to understand the solubility of salt in saliva. The differences in salt origin, raw seawater sources and production specifications lead to sea salt having different particle sizes and shapes that result in the difference of salty taste ${ }^{13}$. Besides, the difference in mineral composition such as potassium, calcium, and magnesium also affects the salty taste of salt ${ }^{14}$. It can be explained by the difference in dissolution kinetics. This research focused on correlation and influence of physico-chemical and particle shape on the dissolution of sea salt in some region in Vietnam. From there, it can shown the characteristics of sea salt in different geographical regions in Vietnam. Normally, conventional linear regression is used to estimate the parameters of equations and their confidence amounts. However, this paper used Bayesian statistics as an alternative method with many advantages over conventional regression method ${ }^{15,16}$. The Bayesian method can be basically applied to approach the linear model for the nonlinear first-order model, or any other model that is deemed suitable ${ }^{15}$.

\section{MATERIALS AND METHODS}

\section{Materials}

Five commercial salt samples and one control were used to evaluate physico-chemical, morphological properties and solubility. Commercial salt samples were collected from other production areas (Table 1): four samples of grain salt from Thanh Hoa (Hoa Loc, Hau Loc Province), Sa Huynh (Duc Pho Province, Quang Ngai), Vung Tau (An Ngai, Long Dien Province), Bac Lieu (Long Dien, Dong Hai Province) and sample of Sa Huynh flower salt (Duc Pho Province, Quang Ngai). Samples are stored at room temperature under conditions of low humidity. Each salt $(500 \mathrm{~g})$ is sieved for $20 \mathrm{~min}$ and the material between sieves net of size $3.00 \mathrm{~mm}, 2.00 \mathrm{~mm}$ and 1.00 $\mathrm{mm}$ is used for analysis dynamics of the dissolution process. This size is present in all samples and is sufficient to be observed with a microscope. The classification of salt samples into two particle sizes helps to minimize errors when analyzing the physical properties and the effect of particle size factors on the dissolution process. The salt samples after sieving are vacuum packed and stored.

\section{Prepare a control sample}

Take $371 \mathrm{~g}$ of $99.5 \%$ pure $\mathrm{NaCl}$ dissolved in distilled water at $60^{\circ} \mathrm{C}$. Then filter the solution through the filter paper and then pour it into the stainless steel trays $(600 \times 400 \times 35 \mathrm{~mm})$ so that the water level reaches $3 \mathrm{~cm}$. Crystallize this solution in an oven at $70^{\circ} \mathrm{C}$ for two days. After crystallizing, the residual brine is removed and the salt is dried to constant weight within the next 12 hours before being packed for storage.

\section{Prepare a solution of artificial saliva}

Artificial saliva (SAGF) was described by Gal \& Fovet (1998) to contain $125.6 \mathrm{mg}$ of $\mathrm{NaCl} ; 963.9 \mathrm{mg} \mathrm{KCl}$; $189.2 \mathrm{mg} \mathrm{KSCN} ; 654.5 \mathrm{mg} \mathrm{KH}_{2} \mathrm{PO}_{4} ; 200 \mathrm{mg}$ Urea; $763.2 \mathrm{mg} \mathrm{Na} \mathrm{SO}_{4} \cdot 10 \mathrm{H}_{2} \mathrm{O} ; 178 \mathrm{mg} \mathrm{NH} \mathrm{NH}_{4} \mathrm{Cl} 227.8 \mathrm{mg}$ $\mathrm{CaCl}_{2} \cdot 2 \mathrm{H}_{2} \mathrm{O}$ and $630.8 \mathrm{mg} \mathrm{NaHCO} 3$ in 1 liter of distilled water ${ }^{12}$. The artificial saliva mixture was stirred for 1 hour at $37^{\circ} \mathrm{C}$ on the magnetic stirrer. The SAGF solution was tested to ensure a $\mathrm{pH}$ of 6.8 and a conductivity of $530-560 \mu \mathrm{S} / \mathrm{cm}$.

\section{Analysis of chemical composition}

The moisture content of salt was determined by MB90 type infrared moisture analyzer (Ohaus, USA), drying at $130^{\circ} \mathrm{C}$ until constant weight. The mineral composition including sodium, potassium, magnesium, calcium and magnesium in salt was determined by flame atomic absorption spectroscopy (VISTA-pro, Varian Canada, Mississauga, ON, Canada). Samples were analyzed in 3 replicates.

\section{Analysis of morphological parameters}

The morphology of the salt was assessed by analyzing the images obtained with an optical microscope. The salt particles were placed on a concave slide and observed under the microscope (OPTIKAM-B9, Optika, Italy) and the images obtained with the Optikam digital camera (OPTIKAM-B3, Optika, Italy) were combined with a microscope and using OptikaView software (Optika, Italy). The captured images were processed and analyzed using Image 1.8.0 software (National Institutes of Health, USA). Parameters describing 2D shape and dimension are determined based on the image analysis. These parameters include: projected area $(\mathrm{A})$; roundness $\left(\mathrm{C}=4 \pi .\left(\mathrm{A} / \mathrm{P}^{2}\right)\right)$ 


\begin{tabular}{llllll}
\hline \multicolumn{2}{l}{ Table 1: Salt in research } & & & \\
\hline Sample & Information of sample & & Sample & Information of sample & \\
& Name of sample & Size of particle & & Name of sample & Size of particle \\
BL1 & Bac Lieu solar salt & $1-2 \mathrm{~mm}$ & BL2 & Bac Lieu solar salt & $2-3 \mathrm{~mm}$ \\
FS1 & Sa Huynh flower of salt & $1-2 \mathrm{~mm}$ & FS2 & Sa Huynh flower of salt & $2-3 \mathrm{~mm}$ \\
M1 & Control sample & $1-2 \mathrm{~mm}$ & M2 & Control sample & $2-3 \mathrm{~mm}$ \\
SH1 & Sa Huynh solar salt & $1-2 \mathrm{~mm}$ & SH2 & Sa Huynh solar salt & $2-3 \mathrm{~mm}$ \\
TH1 & Thanh Hoa solar salt & $1-2 \mathrm{~mm}$ & TH2 & Thanh Hoa solar salt & $2-3 \mathrm{~mm}$ \\
VT1 & Vung Tau solar salt & $1-2 \mathrm{~mm}$ & VT2 & Vung Tau solar salt & $2-3 \mathrm{~mm}$ \\
\hline
\end{tabular}

where $\mathrm{P}$ is projected perimeter; Maximum ferrite diameter (Fmax is the maximum distance between two parallel tangent lines of a particle projected), aspect ratio ( $\mathrm{AR}=$ Spindle $/$ Minor axis of the circumcircle), surface index $(\mathrm{S}=\mathrm{A} / \mathrm{Ac})$ where $\mathrm{Ac}$ is the area of the smallest circumcircle ${ }^{17}$.

\section{Dissolution process analysis in artificial} saliva solution

Dissolution analysis method includes image analysis of microscopic images obtained from Optikam digital cameras (OPTIKAM-B3, Optika, Italy) combined with microscopes (OPTIKAM-B9, Optika, Italy). Image sequences were collected using OptikaView software (Optika, Italy) and recording was started when a grain of salt was placed on a concave slide. Immediately $500 \mu \mathrm{L}$ of a previously preheated SAGF solution at $37^{\circ} \mathrm{C}$ was added. The chosen temperature is close to human body temperature $\left(37^{\circ} \mathrm{C}\right)$ because many salty foods are consumed in this range. The captured images were analyzed using ImageJ 1.8.0 software (National Institutes of Health, USA) and converted into 8-bit images, sharpened and adjusted to the color threshold. The dissolution rate is calculated based on the reduction of the projected area of the salt particle over time and the dissolution kinetics are described by the following three models ${ }^{8,18}$ :

Zero-order model, has the following equation:

$$
A_{t}=-K_{0} \cdot t+A_{0}
$$

First-order model, has the following equation:

$$
\ln \left(A_{t}\right)=-K_{1} \cdot t+\ln \left(A_{0}\right)
$$

Hixon Crowell model, has the following equation:

$$
A_{0}^{1 / 3}-A_{t}^{1 / 3}=K_{s} . t
$$

Where $\mathrm{A}_{t}$ is the projected area of the insoluble salt particles at the time $\mathrm{t}(\mathrm{s}), \mathrm{K}_{0}, \mathrm{~K}_{1} \mathrm{~K}_{S}\left(\mathrm{~s}^{-1}\right)$ is the solubility coefficient and $A_{0}$ is the initial projected area.

\section{Statistical methods}

Differences between samples were determined using ANOVA analysis and LSD test with R software version 4.0.2 (CRAN) ${ }^{19}$. Correlation between morphological parameters and chemical composition was analyzed by Principle Components Analysis - PCA. The dissolution results were calculated by constructing the Bayesian regression equation and the relationship between physical and chemical properties and dissolution was determined by Partial Least Squared - PLS.

\section{RESULTS AND DISCUSSION}

\section{Results of analysis of chemical composition in sea salt}

Table 2 shows the chemical composition of salt samples. Depending on the production area, other mineral components such as $\mathrm{K}, \mathrm{Mg}$ and $\mathrm{Ca}$ were also found in the samples apart from Na. Those non-Na elements have been found to contribute to the salty taste ${ }^{20-22}$. The sodium content varies between samples from different production regions. Vung Tau grain salt has the highest sodium content (337 to 339 $\mathrm{mg} / \mathrm{g}$ ), while Sa Huynh flower salt has the lowest content $(287$ to $289 \mathrm{mg} / \mathrm{g}$ ). Control salt contains few minerals than other samples, while flower salt and Sa Huynh seed salt have the highest total content of other minerals. Humidity showed significant differences between the types of salt (Table 2). Flower salt and Sa Huynh grain salt with the highest humidity (from $10.3 \%$ to $13.7 \%$ ) differ significantly from other salts (from 3.30 to $8.51 \%$ ). In general, most commercial grain salts have a low moisture content, ranging from $3.30 \%$ to $8.51 \%$, which is consistent with the current moisture content requirement of no more than $10 \%$. 


\section{Table 2: Chemical composition of salt samples.}

\begin{tabular}{|c|c|c|c|c|c|}
\hline \multirow[t]{2}{*}{ Sample } & \multicolumn{5}{|c|}{ Chemical composition in 1 gram of salt } \\
\hline & $\mathrm{Na}(\mathrm{mg})$ & $\mathrm{K}(\mu \mathrm{g})$ & $\operatorname{Mg}(\mu \mathrm{g})$ & $\mathrm{Ca}(\mu \mathrm{g})$ & Moisture (\%) \\
\hline BL1 & $314 \pm 1^{e}$ & $668 \pm 1^{i}$ & $2570 \pm 6^{h}$ & $1400 \pm 4^{f}$ & $7.67 \pm 0.03^{f}$ \\
\hline BL2 & $318 \pm 1^{d}$ & $470 \pm 1^{j}$ & $2780 \pm 3^{g}$ & $1460 \pm 2^{e}$ & $8.51 \pm 0.09^{e}$ \\
\hline FS1 & $289 \pm 1^{g}$ & $3490 \pm 2^{a}$ & $10100 \pm 10^{b}$ & $844 \pm 1^{g}$ & $10.20 \pm 0.02^{c}$ \\
\hline FS2 & $287 \pm 1^{g}$ & $3150 \pm 3^{b}$ & $10700 \pm 5^{a}$ & $838 \pm 1^{h}$ & $13.20 \pm 0.20^{b}$ \\
\hline M1 & $389 \pm 2^{a}$ & $<1$ & $<1$ & $<1$ & $<0.01$ \\
\hline M2 & $386 \pm 2^{b}$ & $<1$ & $<1$ & $<1$ & $<0.01$ \\
\hline SH1 & $307 \pm 1^{f}$ & $1570 \pm 5^{d}$ & $8790 \pm 5^{c}$ & $636 \pm 4^{j}$ & $11.30 \pm 0.10^{c}$ \\
\hline SH2 & $308 \pm 1^{f}$ & $1790 \pm 2^{c}$ & $8140 \pm 4^{d}$ & $642 \pm 3^{i}$ & $13.70 \pm 0.10^{a}$ \\
\hline TH1 & $313 \pm 1^{e}$ & $1550 \pm 6^{e}$ & $5240 \pm 3^{f}$ & $2540 \pm 3^{b}$ & $5.45 \pm 0.03^{h}$ \\
\hline TH2 & $317 \pm 2^{d}$ & $1500 \pm 4^{f}$ & $5650 \pm 2^{e}$ & $2660 \pm 3^{a}$ & $6.25 \pm 0.03^{g}$ \\
\hline VT1 & $337 \pm 2^{c}$ & $678 \pm 1^{h}$ & $1900 \pm 2^{j}$ & $1490 \pm 5^{d}$ & $3.30 \pm 0.10^{j}$ \\
\hline VT2 & $339 \pm 3^{c}$ & $824 \pm 2^{g}$ & $2190 \pm 8^{i}$ & $1560 \pm 3^{c}$ & $3.90 \pm 0.03^{i}$ \\
\hline
\end{tabular}

Mean value $(\mathrm{n}=3) \pm$ standard deviation

Mean value represented by different letters in each column indicates significant differences according to ANOVA analysis and LSD test ( $\mathrm{p}$ $<0.05)$.

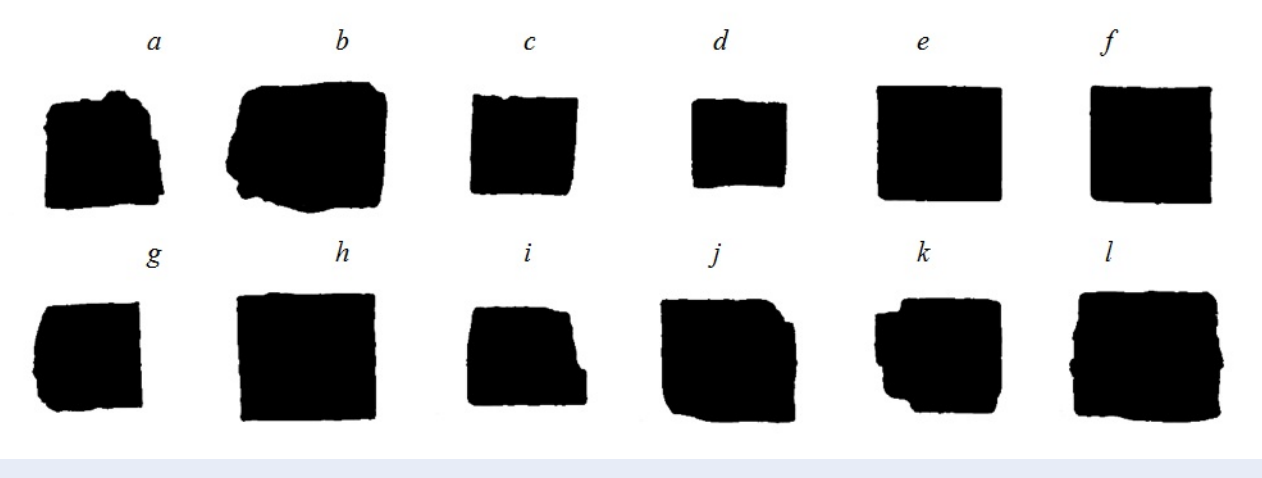

Figure 1: Projected shape of salt samples under an optical microscope (a - BL1, b - BL2, c - FS1, d - FS2, e - M1, fM2, g- SH1, h-SH2, i - TH1, j- TH2, k-VT1, I-VT2)

Results of analysis of morphological parameters

Table 3 compares roundness and surface index between salt samples. Statistically, Sa Huynh flower salt had the smallest area value. The roundness of the salt is affected by the salt crystallization. If the salt samples are crystallized in stable conditions, the salt particles grow evenly between the edges, creating a cube shape and a flat surface, making the roundness and surface index small. The grain salt samples have more angular shapes like convex polygons due to crystallization under unstable conditions with higher roundness and surface index (Figure 1). In terms of frame rate, Sa Huynh flower salt (Figure 1c, Figure 1d) and Sa Huynh grain salt (Figure 1g, Figure 1h) have the highest value, and samples of grain salt in other production areas such as Bac Lieu (Figure 1a, Figure 1b), Thanh Hoa (Figure 1i, 1j), Vung Tau (Figure 1k, Figure 1l) have smaller aspect ratio.

\section{Dissolution analysis results}

The kinetics of the solubility of salt granules in artificial saliva solution shows that there are differences between the different salts. Figure 2 shows the reduction of the projected area with time dissolving in the artificial saliva solution of each salt sample. Two salt 
Table 3: Morphological parameters and size of salt particles determined by optical microscopy.

\begin{tabular}{|c|c|c|c|c|c|}
\hline \multirow[t]{2}{*}{ Sample } & \multicolumn{5}{|c|}{ Morphological and dimensional parameters } \\
\hline & $\begin{array}{l}\text { Projected area } \\
\left(\mathrm{mm}^{2}\right)\end{array}$ & Circulatiry & $\begin{array}{l}\operatorname{Max} \\
(\mathrm{mm})\end{array}$ & Aspect ratio & Solidity \\
\hline BL1 & $3.523 \pm 0.181^{h}$ & $0.727 \pm 0.045^{b}$ & $2.678 \pm 0.133^{f}$ & $1.133 \pm 0.071^{d}$ & $0.963 \pm 0.049^{c d}$ \\
\hline BL2 & $5.322 \pm 0.184^{b}$ & $0.722 \pm 0.042^{b c}$ & $3.235 \pm 0.116^{b}$ & $1.173 \pm 0.084^{b c}$ & $0.992 \pm 0.028^{a}$ \\
\hline FS1 & $2.908 \pm 0.259^{k}$ & $0.692 \pm 0.050^{e}$ & $2.417 \pm 0.149^{h}$ & $1.190 \pm 0.110^{a b}$ & $0.957 \pm 0.050^{d}$ \\
\hline FS2 & $4.597 \pm 0.339^{e}$ & $0.660 \pm 0.079^{f}$ & $3.027 \pm 0.148^{c}$ & $1.212 \pm 0.109^{a}$ & $0.962 \pm 0.049^{c d}$ \\
\hline M1 & $2.655 \pm 0.361^{l}$ & $0.673 \pm 0.078^{e}$ & $2.245 \pm 0.173^{i}$ & $1.198 \pm 0.093^{a b}$ & $0.935 \pm 0.052^{e}$ \\
\hline M2 & $4.487 \pm 0.398^{f}$ & $0.663 \pm 0.086^{f}$ & $2.948 \pm 0.170^{d}$ & $1.220 \pm 0.130^{a}$ & $0.965 \pm 0.048^{c d}$ \\
\hline SH1 & $3.050 \pm 0.287^{j}$ & $0.717 \pm 0.049^{b c}$ & $2.453 \pm 0.146^{h}$ & $1.148 \pm 0.062^{c d}$ & $0.972 \pm 0.045^{b c d}$ \\
\hline $\mathrm{SH} 2$ & $5.188 \pm 0.358^{c}$ & $0.705 \pm 0.043^{c d}$ & $3.217 \pm 0.166^{b}$ & $1.197 \pm 0.145^{a b}$ & $0.972 \pm 0.045^{b c d}$ \\
\hline TH1 & $3.280 \pm 0.223^{i}$ & $0.718 \pm 0.047^{b c}$ & $2.543 \pm 0.123^{g}$ & $1.133 \pm 0.063^{d}$ & $0.960 \pm 0.049^{c d}$ \\
\hline TH2 & $4.730 \pm 0.273^{d}$ & $0.707 \pm 0.041^{b c d}$ & $3.068 \pm 0.141^{c}$ & $1.133 \pm 0.084^{d}$ & $0.975 \pm 0.044^{b c}$ \\
\hline VT1 & $3.842 \pm 0.114^{g}$ & $0.725 \pm 0.047 \mathrm{~b}^{c}$ & $2.743 \pm 0.079^{e}$ & $1.155 \pm 0.079^{c d}$ & $0.983 \pm 0.038^{a b}$ \\
\hline VT2 & $5.715 \pm 0.141^{a}$ & $0.758 \pm 0.050^{a}$ & $3.355 \pm 0.113^{a}$ & $1.200 \pm 0.096^{a b}$ & $0.993 \pm 0.025^{a}$ \\
\hline
\end{tabular}

Mean value $(n=60) \pm$ standard deviation

Mean values expressed in different letters in each column indicate significant differences according to ANOVA analysis and LSD test ( $\mathrm{p}<0.05$ ).

samples of Vung Tau (VT1 and VT2) and Bac Lieu (BL1 and BL2) exhibited very slow reduction in particle projected area with dissolution time and the linear graph is similar to that of the zero-order model. This result is similar to observed in previous study for salt samples with block shape having slower dissolution rate compared to pyramid-shaped samples ${ }^{8}$. On the other hand, Sa Huynh flower salt (FS1 and FS2) and reference salt (M1 and M2) tended to dissolve faster, the salt particle projected area of these samples decreased very quickly, with sugar dissolution graph. Curved is suitable for the first order model. When dissolved in artificial saliva solution, these salt samples have fragmentation phenomenon, increasing the surface area in contact with saliva and dissolving rapidly. Fragmentation of the salt grain may be related to the crystal's internal structure. Samples of grain salts without fragmentation during dissolution indicated that these samples were structurally tight. In contrast, Sa Huynh flower salt has a porous, lightgrain structure with many pores so fragmentation is observed during the dissolution. In addition, samples of Thanh Hoa grain salt (TH1 and TH2), Sa Huynh (SH1 and $\mathrm{SH} 2$ ) have curve-shaped solubility graph but do not show the nonlinear model clearly, it is possible to apply Hixon Crowell model to show the best solubility of all salt samples ${ }^{16}$.

The solubility coefficient results of salt samples calculated from the regression equation of Hixson Crowell model by Bayesian method are presented in Table 5 . Samples of Sa Huynh flower salt and control salt have the highest solubility coefficient. While the salt samples in Bac Lieu and Vung Tau have a lower solubility coefficient than other salt samples. This is shown when the greater the solubility coefficient, the faster the salt dissolves or the shorter the total dissolution time, and vice versa. This result also shows the effect of particle size on the dissolution rate when larger salt samples (BL2, FS2, M2, SH2, TH2 and VT2) have lower solubility coefficients.

\section{Discussion on characteristics}

\section{Correlation between physical and chemical properties.}

The analysis results from the PCA correlation circle showed a very large correlation between the roundness of the grain and the chemical composition of the salt (Figure 3 ). This result clearly shows the specifics and differences in physical and chemical properties in the two samples of flower salt and Sa Huynh grain salt compared to the remaining salt samples, which are AR and moisture, magnesium, potassium content. At the same time, morphological parameters also showed that projected area parameters and maximum ferrite diameter also have a very clear positive correlation. Most physical properties exhibit an inverse correlation with the potassium, magnesium and 


\begin{tabular}{llll}
\hline Table 4: $\mathbf{R}^{2}$ values of dissolution kinetic models & & \\
\hline Sample & Zero - order & First - order & Hixon Crowell \\
BL1 & 0.9781 & 0.9850 & 0.9893 \\
BL2 & 0.9850 & 0.9904 & 0.9903 \\
FS1 & 0.9562 & 0.9407 & 0.9884 \\
FS2 & 0.9589 & 0.9535 & 0.9882 \\
M1 & 0.9488 & 0.9433 & 0.9882 \\
M2 & 0.9567 & 0.9428 & 0.9871 \\
SH1 & 0.9760 & 0.9634 & 0.9869 \\
SH2 & 0.9777 & 0.9861 & 0.9888 \\
TH1 & 0.9752 & 0.9850 & 0.9902 \\
TH2 & 0.9841 & 0.9877 & 0.9929 \\
VT1 & 0.9797 & 0.9858 & 0.9868 \\
VT2 & 0.9782 & 0.9821 & 0.9813 \\
\hline
\end{tabular}

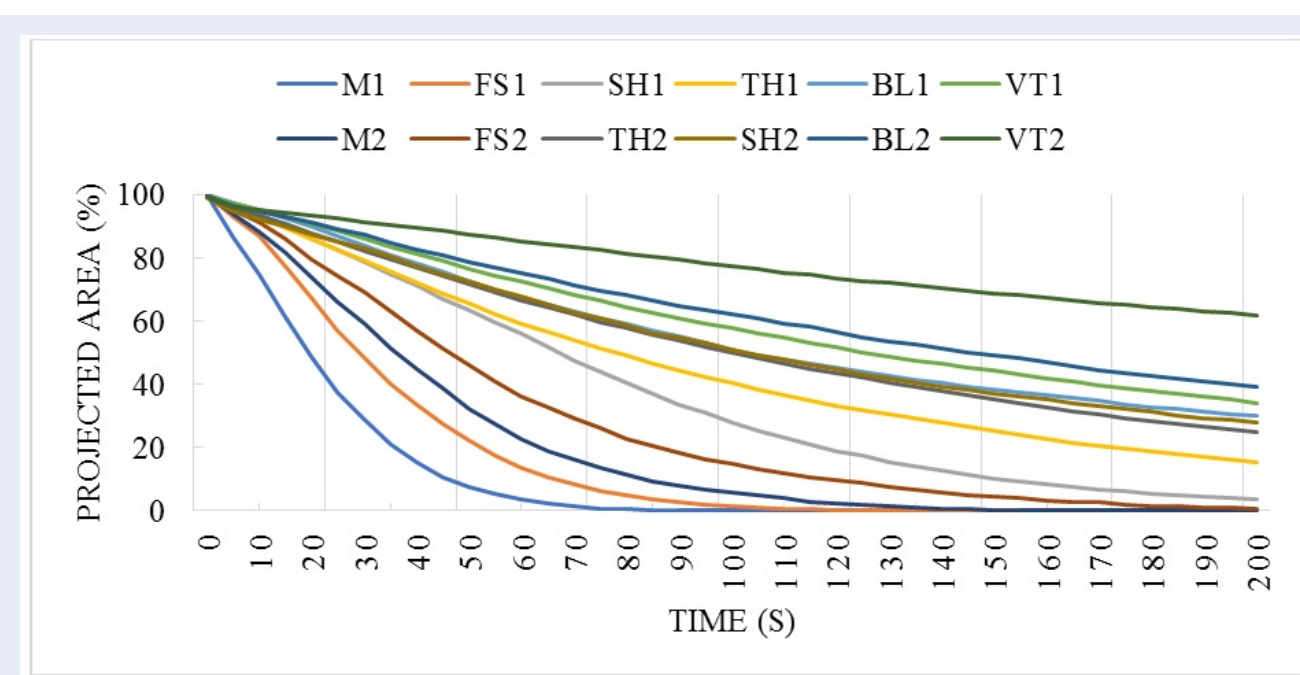

Figure 2: Projected area of salt samples under an optical microscope.

moisture content, while positively correlating with the sodium and calcium content. This shows that during natural crystallization, the purer the salt samples or the higher their sodium content, the shape and size of the salt also differ from those with lower sodium content.

Salt samples also showed significant differences in physical and chemical properties by region of production. Sa Huynh flower salts and grain salt have high levels of magnesium, potassium, and moisture, which are very round. Salt from Vung Tau, Bac Lieu has high sodium content, high roundness and surface index. Thanh Hoa salt showed a distinct difference in the high calcium content.

\section{Evaluate the influence of chemical and phys- ical properties on the solubility of salt}

To evaluate the effect of physical and chemical properties on the salt solubility, we conduct PLSR analysis with solubility coefficient calculated from the regression equation according to Bayesian method as dependent variable and 5 physical parameters (Area, Feret's Diameter, Circularity, Aspect Ratio and Solidity) as well as 5 chemical parameters (sodium, potassium, magnesium, calcium and moisture content) as independent variables. The result of RMSEP shows 
Table 5: Values from the regression equation following the Bayesian method of salt dissolution.

\begin{tabular}{llll}
\hline Sample & \multicolumn{2}{l}{ Equivalence coefficient and $90 \%$ credible interval } & \\
& Coefficient & $2,5 \%$ Credible Interval & $97,5 \%$ Credible Interval \\
BL1 & $0.010 \pm 0.005^{g h}$ & $0.009 \pm 0.005^{g h}$ & $0.010 \pm 0.005^{g}$ \\
BL2 & $0.007 \pm 0.001^{i}$ & $0.006 \pm 0.001^{i}$ & $0.007 \pm 0.002^{h}$ \\
FS1 & $0.038 \pm 0.006^{b}$ & $0.036 \pm 0.005^{b}$ & $0.039 \pm 0.007^{b}$ \\
FS2 & $0.022 \pm 0.004^{d}$ & $0.021 \pm 0.004^{d}$ & $0.023 \pm 0.005^{d}$ \\
M1 & $0.057 \pm 0.014^{a}$ & $0.054 \pm 0.013^{a}$ & $0.060 \pm 0.015^{a}$ \\
M2 & $0.030 \pm 0.005^{c}$ & $0.029 \pm 0.005^{c}$ & $0.031 \pm 0.006^{c}$ \\
SH1 & $0.017 \pm 0.003^{e}$ & $0.016 \pm 0.003^{e}$ & $0.017 \pm 0.003^{e}$ \\
SH2 & $0.009 \pm 0.005^{g h}$ & $0.009 \pm 0.005^{g h}$ & $0.010 \pm 0.005^{g}$ \\
TH1 & $0.012 \pm 0.004^{f}$ & $0.012 \pm 0.004^{f}$ & $0.012 \pm 0.004^{f}$ \\
TH2 & $0.010 \pm 0.004^{g}$ & $0.010 \pm 0.004^{g}$ & $0.010 \pm 0.005^{g}$ \\
VT1 & $0.008 \pm 0.003^{h i}$ & $0.008 \pm 0.003^{h i}$ & $0.008 \pm 0.003^{g h}$ \\
VT2 & $0.004 \pm 0.001^{j}$ & $0.003 \pm 0.001^{j}$ & $0.004 \pm 0.001^{i}$ \\
\hline
\end{tabular}

Mean value $(\mathrm{n}=60) \pm$ standard deviation

Mean values expressed in different letters in each column indicate significant differences according to ANOVA analysis and LSD test ( $\mathrm{p}<0.05)$.
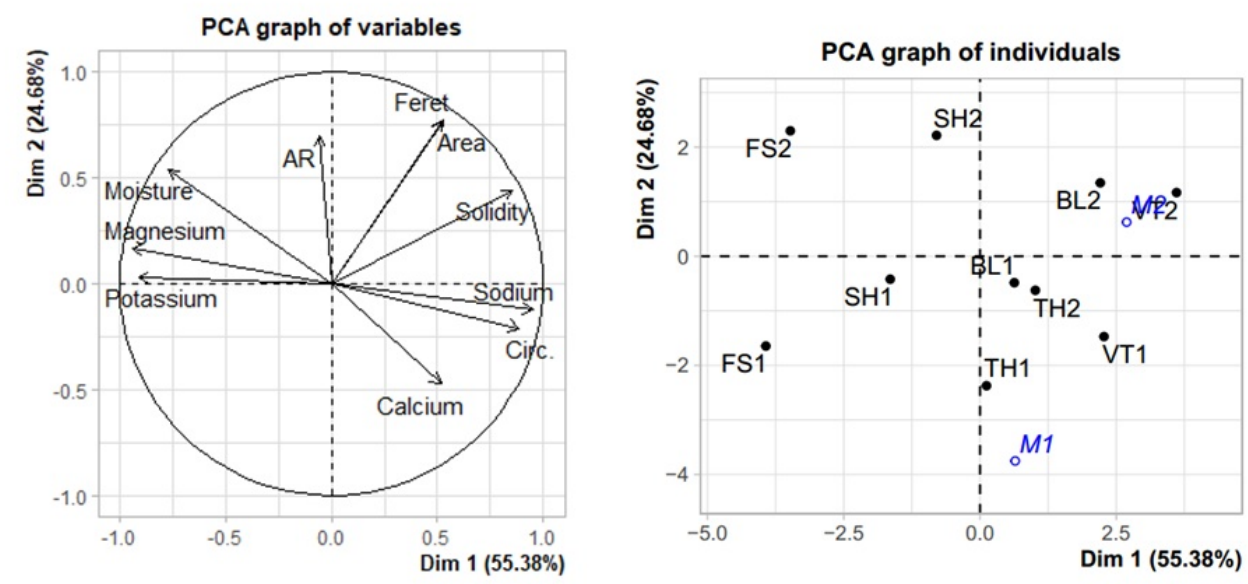

Figure 3: Results of PCA correlation circle

that when evaluating combinations of factors, the combination of 6 factors shows the best explanation due to the lowest RMSEP value of the 10 combinations is considered (Figure 4).

The analysis results of Variable Importance in Projected - VIP coefficients in the combination of 6 factors showed a clear influence of physical and chemical properties which is presented in Table 6. The results showed that the chemical composition has a great influence on the dissolution process when the sodium, magnesium, potassium and calcium contents have the highest VIP coefficients of the factors assessed. In there, magnesium showed the highest influcence on dissolution process. This is possible because magnesium binds hydration water more tightly than calcium, potassium, and sodium when dissolved, as a result, the hydrated magnesium cation is difficult to dehydrate. Among physical properties, Area parameter has the highest coefficient, proving that this is an important physical factor to consider when evaluating the solubility of salt. The results also show that the moisture content also has a slight influence on the 


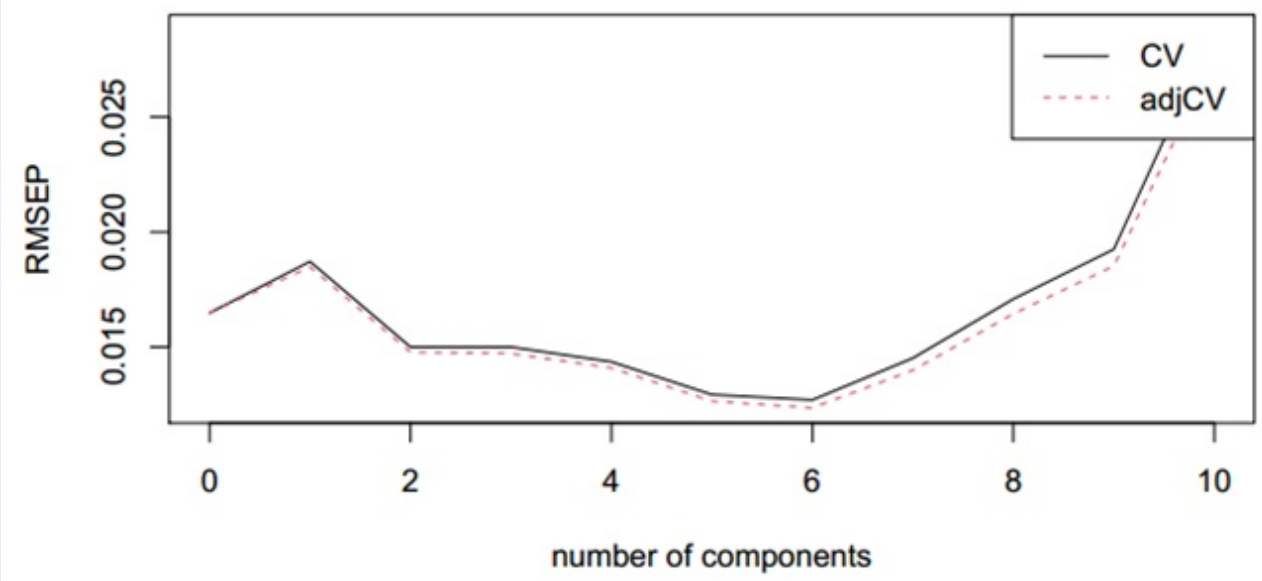

Figure 4: Root Mean Squared Error of Prediction graph of solubility coefficient.

dissolution process as the moisture's VIP coefficient is clearly different from the remaining physical parameters.

\section{CONCLUSIONS}

The results of the solubility of salt samples from 1 to 2 $\mathrm{mm}$ and 2 to $3 \mathrm{~mm}$ in size in artificial saliva solution have shown that salt type, morphology and chemical composition are influential factors affecting dissolving speed. Flower salts dissolve much faster than grain salt. Projected particle area parameters and sodium, potassium, calcium, and magnesium content are the main physical and chemical factors that have great correlation with the solubility process. The mineral composition influences the taste perception of salt (potassium is acidic and magnesium is bitter). Therefore, the adjustment of salt crystallization in production and the chemical composition change the sensory properties of salt. This problem required further, study on the effect of the physical and chemical factor on the salinity sensory properties of salt samples of different origin.

\section{LIST OF ABBREVIATIONS}

AR: Aspect ratio

Ca: Calcium

Cir.: Circularity

Feret: Feret's Diameter

Mg: Magnesium

PLS: Partial Least Squared

PLSR: Partial Least Squares Regression

PCA: Principle Components Analysis

K: Potassium

RMSEP: Root Mean Squared Error of Prediction
SAGF: Saliva Artificial Gal - Fovet solution

Na: Sodium

VIP : Variable Importance in Projected

\section{COMPETING INTEREST}

The authors declare that they have no competing interestes.

\section{AUTHORS' CONTRIBUTION}

Nguyen Huu Lan: The conception and design of the study, Writing - original draft. Nguyen Thi Ngoc Huong: Methodology, Data curation. Pham Huu Thinh: Formal analysis. Lai Quoc Dat: Methodology, Writing - review and editing. Nguyen Hoang Dzung: Funding acquisition, Supervision, Validation.

\section{REFERENCES}

1. Kaushik S, Kumar R, Kain P. Salt an Essential Nutrient: Advances in Understanding Salt Taste Detection Using Drosophila as a Model System. J Exp Neurosci. 2018;12:112;PMID: 30479487. Available from: https://doi.org/10.1177/ 1179069518806894.

2. McLean RM, Petersen KS, Arcand J, Malta D, Rae S, Thout SR, et al. Science of Salt: A regularly updated systematic review of salt and health outcomes studies (April to October 2018). J Clin Hypertens. 2019;21(8):1030-42;PMID: 31245918. Available from: https://doi.org/10.1111/jch.13611.

3. Elias M, Laranjo M, Agulheiro-Santos AC, Potes ME. The role of salt on food and human health. Salt Earth. 2020;19;Available from: https://doi.org/10.5772/intechopen.86905.

4. Khokhar D, Nowson CA, Margerison C, Bolam B, Grimes CA. Knowledge and attitudes are related to selected saltspecific behaviours among Australian parents. Nutrients. 2018;10(6):720;PMID: 29867025. Available from: https://doi. org/10.3390/nu10060720.

5. Farrand C, MacGregor G, Campbell NRC, Webster J. Potential use of salt substitutes to reduce blood pressure. J Clin Hypertens. 2019;21(3):350-4;PMID: 30690859. Available from: https://doi.org/10.1111/jch.13482. 


\section{Table 6: Variable Importance in Projected.}

\begin{tabular}{|c|c|c|c|c|c|c|c|c|c|c|}
\hline \multirow[t]{2}{*}{ Specimen } & \multicolumn{10}{|c|}{ Variable Importance in Projected (VIP) } \\
\hline & Area & Circ. & Feret & AR & Solidity & $\mathrm{Na}$ & Moisture & $\mathrm{Ca}$ & $\mathrm{Mg}$ & $\mathrm{K}$ \\
\hline $\begin{array}{l}\text { Variable im- } \\
\text { portance } \\
\text { in Projected }\end{array}$ & 1.13 & 0.03 & 0.39 & 0.04 & 0.02 & 1.48 & 0.86 & 0.96 & 1.89 & 1.07 \\
\hline
\end{tabular}

6. Agócs R, Sugár D, Szabó AJ. Is too much salt harmful? Yes. Pediatr Nephrol. 2019;1-9;PMID: 31781959. Available from: https://doi.org/10.1007/s00467-019-04387-4.

7. Roebber JK, Roper SD, Chaudhari N. The role of the anion in salt $(\mathrm{NaCl})$ detection by mouse taste buds. J Neurosci. 2019;39(32):6224-32;PMID: 31171579. Available from: https: //doi.org/10.1523/JNEUROSCI.2367-18.2019.

8. Quilaqueo M, Duizer L, Aguilera JM. The morphology of salt crystals affects the perception of saltiness. Food Res Int. 2015;76:675-81;PMID: 28455052. Available from: https://doi. org/10.1016/j.foodres.2015.07.004.

9. Doyle ME, Glass KA. Sodium reduction and its effect on food safety, food quality, and human health. Compr Rev food Sci food Saf. 2010;9(1):44-56;PMID: 33467812. Available from: https://doi.org/10.1111/j.1541-4337.2009.00096.x.

10. Rama R, Chiu N, Carvalho Da Silva M, Hewson L, Hort J, Fisk ID. Impact of salt crystal size on in-mouth delivery of sodium and saltiness perception from snack foods. J Texture Stud. 2013;44(5):338-45;Available from: https://doi.org/10.1111/jtxs. 12017.

11. Carpenter G. Role of saliva in the oral processing of food. Food Oral Process Wiley-Blackwell. 2012;45-60;Available from: https://doi.org/10.1002/9781444360943.ch3.

12. Vella $D$, Marcone $M$, Duizer LM. Physical and sensory properties of regional sea salts. Food Res Int. 2012;45(1):41521;Available from: https://doi.org/10.1016/j.foodres.2011.11. 013.

13. Sun C, Zhou X, Hu Z, Lu W, Zhao Y, Fang Y. Food and salt structure design for salt reducing. Innov Food Sci Emerg Technol. 2020;102570;Available from: https://doi.org/10.1016/ j.ifset.2020.102570.

14. Drake SL, Drake MA. Comparison of salty taste and time intensity of sea and land salts from around the world. J Sens Stud. 2011;26(1):25-34;Available from: https://doi.org/10. 1111/j.1745-459X.2010.00317.x.

15. Hobbs NT, Hooten MB. Bayesian models: a statistical primer for ecologists. Princeton University Press; 2015;Available from: https://doi.org/10.1515/9781400866557.

16. Boekel M. On the pros and cons of Bayesian kinetic modeling in food science. Trends Food Sci Technol. 2020;99:181 93;Available from: https://doi.org/10.1016/j.tifs.2020.02.027.

17. Olson E. Particle shape factors and their use in image analysis part II: practical applications. J GXP Compliance. 2011;15.4(77);

18. Costa P, Lobo JMS. Modeling and comparison of dissolution profiles. Eur J Pharm Sci. 2001;13:123-33;Available from: https: //doi.org/10.1016/S0928-0987(01)00095-1.

19. Team RC. R: A Language and Environment for Statistical 2017. ISSN 3-900051-07-0;Available from: http://www.r-project.org.

20. Van Der Klaauw NJ, Smith D V. Taste quality profiles for fifteen organic and inorganic salts. Physiol Behav. 1995;58(2):295-306;Available from: https: //doi.org/10.1016/0031-9384(95)00056-O.

21. YANG HH, Lawless HT. Descriptive analysis of divalent salts. J Sens Stud. 2005;20(2):97-113;PMID: 16614749. Available from: https://doi.org/10.1111/j.1745-459X.2005.00005.x.

22. Murphy C, Cardello A V, Brand JG. Tastes of fifteen halide salts following water and $\mathrm{NaCl}$ : anion and cation effects. Physiol Behav. 1981;26(6):1083-95;Available from: https://doi.org/10. 1016/0031-9384(81)90213-4. 


\title{
Ảnh hưởng của các tính chất vật lý và hóa học đến quá trình hòa tan của muối biển
}

\author{
Nguyễn Hữu Lân, Nguyễn Thị Ngọc Hương, Phạm Hữu Thịnh, Lại Quốc Đạt, Nguyễn Hoàng Dũng*
}

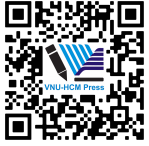

Use your smartphone to scan this QR code and download this article

\section{TÓM TẮT}

Muối có vai trò quan trọng trong sức khỏe con người. Tuy nhiên, sử dụng quá nhiều $\mathrm{NaCl}$ trong các sản phẩm thực phẩm có thể ảnh hưởng xấu đến sức khỏe. Một hướng giải quyết vấn đề này là cần tối ưu quá trình hòa tan muối để tăng hàm lượng các ion của muối trong miệng. Để thực hiện điều đó, điều quan trọng là cần hiểu các đặc tính hòa tan của tinh thể muối trong nước bọt Quá trình hòa tan của muối không chỉ bị ảnh hưởng bởi các tính chất vật lý mà còn bị ảnh hưởng bởi thành phần hóa họ của muối. Nghiên cứu so sánh độ hòa tan của 4 mâũ muối thương mai từ 4 khu vực ở Việt Nam (Bạc Liêu, Thanh Hóa, Sa Huỳnh, Vũng Tàu), 1 mâũ muối hoa từ Sa Huỳnh và 1 mâũ đối chứng ở 2 kích thước là $1-2 \mathrm{~mm}$ và $2-3 \mathrm{~mm}$ trong dung dịch nước bọt nhân tạo Gal - Fovet (SAGF). Sự hòa tan được phân tích qua hình ảnh tinh thể dưới kính hiển vi theo thời gian, xử lý kết quả bằng phương pháp Bayesian và bình phương tối thiểu từng phần (PLS). Nghiên cứu đánh giá sự ảnh hưởng của các tính chất vật lý (diện tích hình chiếu, đường kính Feret, độ tròn, tỷ lệ khung hình và chỉ số bề mặt) và các tính chất hóa học (Natri, Kali, Magie, Canxi và độ ẩm) đến quá trình hòa tan. Các mâũ muối cho thấy sự khác nhau đáng kể về tính chất vật lý và hóa học theo khu vực địa lý. Các thông số hình học bị ảnh hưởng bởi điều kiện kết tinh, điều này thể hiện qua nguồn gốc các mâũ. Độ hòa tan được đánh giá qua hệ số hòa tan, muối hoa Sa Huỳnh và mâũ đối chứng có hê số hòa tan cao nhất, đồng thời, cũng có giá trị độ tròn và chỉ số bề mặt nhỏ nhất Diện tích hình chiếu, hàm lượng Magie và natri là những yếu tố ảnh hưởng mạnh nhất. Kết quả thể hiện khả năng khai thác các yếu tố này để điều chỉnh độ hòa tan của muối cũng như sự cảm nhận đồ mặn theo thời gian.

Từ khoá: muối, nước bọt nhân tạo, hòa tan, tính chất hóa lý, Bayesian
Bộ môn Công nghệ Thưc phẩm, Đai hoc Bách Khoa, ĐHQG-HCM, TP. Hồ Chí Minh, Viêt Nam

Liên hệ

Nguyễn Hoàng Dũng, Bô môn Công nghệ Thực phẩm, Đại học Bách Khoa, ĐHQG-HCM, TP. Hồ Chí Minh, Việt Nam

Email: dzung@hcmut.edu.vn

Lịch sử

- Ngày nhận: 25-3-2021

- Ngày chấp nhận: 27-5-2021

- Ngày đăng: 03-6-2021

DOI : 10.32508/stdjet.v4i2.822

\section{Check for updates}

\section{Bản quyền}

๑ Đ ĐHQG Tp.HCM. Đây là bài báo công bố mở được phát hành theo các điều khoản của the Creative Commons Attribution 4.0 International license.

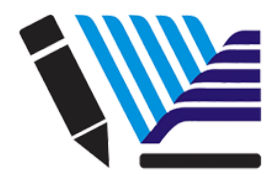

VNU-HCM Press
Trích dẫn bài báo này: Lân $\mathrm{N} \mathrm{H}$, Hương $\mathrm{N} T \mathrm{~N}$, Thịnh $\mathrm{P} \mathrm{H}$, Đat $\mathrm{L} \mathrm{Q}$, Dũng $\mathrm{N} \mathrm{H}$. Ảnh hưởng của các tính chất vật lý và hóa học đến quá trình hòa tan của muối biển . Sci. Tech. Dev. J. - Eng. Tech.; 4(2):1009-1018. 